DE

\title{
Je ne suis pas Charlie. Metadiscourses of impoliteness following "France's 9/11" in selected print media
}

\author{
Milan Ferenčík \\ University of Prešov, Slovakia
}

\begin{abstract}
Almost immediately after the Charlie Hebdo shootings of 7 January 2015 , some print media made room for alternative opinions of what had happened. The articles and the discussions they inspired are replete with evaluations which lend themselves to analysis using methods and procedures of Politeness Theory. The paper examines an example of a metadiscourse of (im)politeness which questions the "moral orders" underlying the cartoonists' as well as other participants' social practices vis-à-vis their ideological foundations, esp. freedom of speech as one of the principal liberties of our society. To that end, the approach to politeness as "social practice" is employed which, while insisting on multiple understandings of politeness, places participants' evaluations at the centre of politeness research.
\end{abstract}

\section{Keywords}

Charlie Hebdo shooting, impoliteness, metacomment, politeness as discursive struggle, politeness as social practice

\section{Introduction}

The quote from my example of a metadiscourse, i.e. a discourse about discourse(s), succinctly formulates the position in which many people seemed to become "trapped" following the deadly attacks on Charlie Hebdo's staff on 7 January 2015 and who, while decrying the murders, did not approve of Charlie Hebdo's satirical journalistic practices which preceded them. By drawing our attention to the tension between the illocutionary force of the cartoons depicting the prophet and the social goals which they were perceived to meet, viz. that of a face-attack, the quote invokes the role of evaluations of others' behaviour, as well as our own, which are made against the background of the norms that have been established in the sociocultural groups to which the evaluators claim to belong. The killings, and the ensuing developments over the following months, further aggravated an already tense atmosphere in Europe and added another layer of discourse about violence and aggression which was extensively covered in European mainstream mass media and ultimately invited audiences to take positions. The "Charlie Hebdo discourses" almost immediately polarized the European populace along two opposing memes: Je suis Charlie and Je ne suis pas Charlie. While the former sprang out as an immediate and spontaneous negative evaluation of the infamous violent act and sought to become primarily an expression of solidarity with the victims and identification with the values which they professed, esp. freedom of speech, the latter began to express a critical position towards this identification by pinpointing the fact that freedom is not without limits. The "Charlie Hebdo discourses" which appeared on the pages of print media and in the discussion fora underneath the articles are rich in evaluations addressing the (in)appropriateness of this violent act, as well as of the Charlie Hebdo practices regarded as having engendered it, and thus offer possibilities of insight into how societal 
norms are "struggled over" vis-à-vis the identities taken up by the actors of these disputes. The lexical-semantic layer of these discourses testifies to the actors' metapragmatic awareness and offers analysts a wealth of pragmatic data for scrutiny. My goal in the paper is to use the methods and procedures resulting from current approaches within Politeness Theory (PT) and to demonstrate their feasibility in accounting for how debates following a major societal disruption lead to a reassessment of the underlying system of values upon which sociocultural groups are founded.

\section{Politeness Theory - an overview}

In the course of just over forty years the area within pragmatics known as PT has not only gone through an emergence, rapid rise and extensive growth of empirical research but also through a rethinking of its major tenets and approaches, until it has stabilized into a fully-fledged multidisciplinary domain of social research. It grew in the latter half of the past century as a reaction to the "pragmatic turn" which brought about a reorientation of research focus from langue to parole and from linguistic to communicative competence. Ever since, politeness thinking and practice has been seen as evolving in three "waves" of approaches (Grainger 2011).

\subsection{The first-wave approaches - the classic/pragmatic period}

Lakoff (1973), the pioneer of politeness research, found pragmatic rules of wellformedness on a par with those of a syntactic nature which controlled syntactic well-formedness and which, ultimately, determined the grammatical competence of an ideal speaker/hearer, who was the primary focus of interest of Chomskyan linguistics. Lakoff used the insight of the advances in ordinary language philosophy, viz. Austin's Speech Act Theory and Grice's Co-operative Principle, and incorporated them into her model of pragmatic competence. While Grice himself made only a passing note that, besides the maxims of quality, quantity, manner and relevance there are possibly other maxims in operation, such as the politeness maxim, it was Lakoff who was the first to explicitly formulate the "Be polite" rule as the second of the two pragmatic rules (the first being Grice's Co-operative Principle in the guise of the formulation "Be clear"). Lakoff later expanded the "Be polite" rule by further specifying the three sub-rules, viz. "Don't impose", "Give options" and "Make [alter] feel good - be friendly". Through her groundbreaking study Lakoff delineated many of the future developments in politeness theory and practice, especially in its "classic" period. A similar task of developing Grice's ingenious remark was tackled by Leech (1983), who devised the "Politeness Principle" as a finer system of six politeness maxims based on several pragmatic scales, and placed it alongside Grice's Co-operative Principle within his more general framework of "Interpersonal Rhetoric". Both Lakoff and Leech represent the core pragmatic approaches to politeness by assuming that interlocutors behave rationally, i.e. use means-ends reasoning to calculate why their partners depart from co-operation. For both authors, politeness is a constraint on human behaviour which is motivated by the need to minimize conflict and/or confrontation (Lakoff) and avoid discord/maintain concord (Leech).

The bias towards the "polite" dimension of interpersonal relationships also marks the third approach to politeness in the triad of politeness classics, viz. Brown and Levinson's (1978/87) model, which became and has remained the most influential, best known and most widely used ever since it was conceived (1978) and reworked (1987). The concepts they proposed form the conceptual basis of PT and have become widely known outside the discipline. Among them, the social-psychological concept of "face" (which they took over from Goffman (1955)) occupies a central place, along with other terms such as "positive face", "negative face", "face-threatening act" and several others. Like Lakoff and Leech, Brown and Levinson also view politeness as the strategically planned, rational behaviour of a "model person" aimed at countering a

1 In Politeness Theory, the notion of a Model Person represents a construct of an ideal interlocutor who is assigned the capacity to rationalize from communicative goals to expressive means and, when trying to be "polite", to use those strategies which consider the hearer's face wants. Thus, the five politeness strategies as suggested by Brown and Levinson (1987) are the result of the Model Person's rational means-ends reasoning through which he departs from the maximum efficiency, and "sacrifices" cooperation (as captured in Grice's 
potentially adverse impact upon one's face. The face-threat inherent, as they claim, in virtually any type of behaviour is to be averted or at least minimized by a strategy chosen from an array of choices which rational users have at their disposal. These unprecedentedly detailed strategies led to an upsurge of research into politeness issues worldwide.

The criticism levelled at the pragmatic foundations of the models was principally directed at their Western bias, which was claimed to be present in the rationalitybased behaviour of an individual and also in the conception of individual face $^{2}$ which promoted Western values. Brown and Levinson's claims for universality were contested and challenged especially by nonWestern researchers. Other criticism was made about the focus on isolated utterances

Cooperative Principle), but whose ultimate aim is to maintain "social equilibrium".

2 Face is generally seen as a "relational construct" which becomes meaningful only through the dis/approval of others and is constantly attended to in interaction since it is in the best interests of all interactants to maintain each other's face: "everyone's face depends on everyone else's being maintained" (Brown and Levinson, 1987, p.61). O'Driscoll (2011) demonstrates this reciprocal nature of face through the presence of "fellow-feeling" among participants who assume a certain share of responsibility in the situation in which a face-threat is performed. As he claims, this fellow-feeling is "built into us as interactants", and "[i]t is in this reciprocal nature - whereby damage to one person's face leads to the damage of everybody's face - and the repair of that face simultaneously involves the repair of all faces - that the phenomenon of face may be described as 'real'" (O'Driscoll, 2011 , p.19). Hence, a facethreatening act potentially threatens all participants' faces, despite the fact that they may have a different degree of commitment to and/or presence in the act (cf. Figure 2). This applies both to face-to-face as well as to "dislocated", i.e. mediated communication, since "it is quite possible that we habitually behave with an eye to our faces in all modes, that we project them onto the page, or screen or into the mouthpiece." (O'Driscoll, 2011, p.27) (which betrayed a strong Speech Act Theory influence) produced by the speaker and their emphasis on the production pole of a communication event, and ultimately, a possible lack of correspondence between theoretical and lay understanding of what polite behaviour is. Efforts to rectify the problems inherent in the "classic" period of politeness research were made in the subsequent decades.

\subsection{The second-wave approaches - the post-pragmatic period}

In the early 1990s the first seeds of a substantial shift in politeness theorizing were sown and new trends in its scope and methodology were forecast. Watts et al. (1992) were among the first to suggest that politeness is a "marked surplus" phenomenon that is identifiable against a background of unmarked, expected (or, as it was called, "politic") behaviour. The suggestion was further developed by Watts (2003) and by Locher and Watts (2005) and elaborated as an approach that came to be known as "politeness as a discursive struggle". The focus on situated evaluations of politeness made by the interlocutors themselves in the course of negotiating their interpersonal relationship, or "relational work", became the major theoreticalmethodological shift marking the emergence of the post-pragmatic politeness modelling. Its proponents claim that the evaluative nature of politeness causes it to be a contestable phenomenon, which engenders its variability and relativity, even to a (somewhat extreme) degree: "Politeness is like beauty, it's in the eye of the beholder" (Locher and Watts, 2005, p.29). It is to be noted that the notion of the contestedness of politeness evaluations was antedated by Lakoff herself in her remark that "what is polite for me may be rude for you"; Lakoff, 1973 , p. 303). Further, (im)politeness evaluations are claimed to be made within smaller sociocultural groups called "communities of practice" (the concept was adopted from Wenger, 1998) and are relative to the value systems these communities have negotiated and agreed upon. Ultimately, the "classic" dichotomy of politeness vs. impoliteness is abandoned in favour of a much finer range of evaluations which members of sociocultural groups have at their disposal in rich inventories of evaluative concepts to judge each other's behaviour, with "politeness" being only one of such labels. Finally, the notion of 
"facework", which was seen as too closely tied with Brown-and-Levinsonian face-threat mitigation, was replaced by "relational work", which was conceptualized as encompassing "all aspects of the work invested by individuals in the construction, maintenance, reproduction and transformation of interpersonal relationships among those engaged in social practice" (Locher and Watts, 2008, p.96).

The radical changes that took place in politeness research in the 1990s and 2000s brought about a reassessment of nearly every aspect of the previous approaches and can be briefly summarized here:

- extending the scope of interest from politeness seen as facemaintaining/enhancing (harmonious, conflict-free behaviour) to faceaggravating, face-damaging (aggressive, conflicting behaviour), or impoliteness/rudeness, which grew into a strand of "impoliteness research" in its own right;

- studying politeness-related phenomena within larger spectrums of negotiating interpersonal relationships, such as "relational work" (Locher and Watts, 2005; 2008), "rapport management" (Spencer-Oatey, 2005), "faceconstituting theory" (Arundale, 2010);

- extending researchers' interest from the theoretical $\left(2^{\text {nd }}\right.$ order) to lay $\left(1^{\text {st }}\right.$ order) conceptualization of politeness, and from isolated acts to extended exchanges of turns;

- crossing over to related fields of social science, such as social psychology, sociolinguistics and cognitive science, and bridging politeness research with identity construction, emotions and cognition (Locher, 2011).

\subsection{The third-wave approaches - the interactionist period}

These trends culminated in the 2010s with a book-length publication by Kádár and Haugh (2013) which seems to be the most thorough synthesis and systematization yet of what is known about politeness phenomena and the processes of their emergence and evaluation. While offering no original politeness model of its own, its merit lies in drawing our attention to politeness being a social practice in its own right:
Politeness is a social practice [...] because it involves evaluations occasioned by social actions and meanings that are recognisable to participants. [S]social actions and meanings necessarily draw on normative practices, ways of formulating talk and conduct that are understood by participants as doing and meaning certain things. (Kádár and Haugh, 2013, p.66; original emphasis) It is possible to draw attention here to only some of their many interesting observations. First of all, they extend the notion of the variability of politeness to the fact that there are multiple different understandings of politeness depending on the participation statuses of those involved in politeness evaluations. They offer a much more nuanced array of categories of persons, or participation footings, which goes beyond the mere "speaker" and "hearer". As they see it, politeness goes beyond the use of linguistic forms (usage); it is pervasive and permeates all human interactions. Finally, politeness evaluations are made with regard to the underlying set of norms, or "moral orders" (MO) which have been negotiated within specific sociocultural groups. Kádár and Haugh's (2013) approach, which forms the backbone of my analysis, also draws our attention to other aspects of politeness, such as the metapragmatics of politeness as an important key to evaluations, layers of MO as a backdrop of evaluations, cognitive and emotional underpinnings of politeness, and many others.

\subsection{A return to the pragmalinguistic roots of politeness - Leech (2014)}

While the major thread of sociopragmatic politeness research over the past two decades has greatly increased our awareness of the multifarious aspects that need to be taken into account when studying this phenomenon, it has in fact not progressed very much in our understanding of what politeness actually is. As a result, the approaches often border on relativism and are of limited generalizability and predictability. There is little agreement on the "content" of politeness other than it is a phenomenon which is contested, variable and open to evaluation with regard to specific norms; politeness thus still remains a "slippery" and elusive concept (Watts, 2003). In order to rectify the situation and find firm ground upon which to base our thinking about politeness anew, Geoffrey Leech (2014) undertook to rethink his classic (1983) approach and proposed a reworked 
politeness model in which he returns to the language as a starting point in thinking about politeness as a "constraint observed in human communicative behaviour, influencing us to avoid communicative discord or offence, and maintain or enhance communicative concord or comity" (Leech, 2014 , p.87). His return to the pragmalinguistic roots of politeness has brought about a critical reassessment of his earlier model vis-à-vis the developments within politeness research and within pragmatic thinking in general over the three decades. His understanding of politeness as "communicative altruism" is both general enough to enable cross-cultural comparison and flexible enough to accommodate situated evaluations $(\mathrm{O}=$ other person/people):

General Strategy of Politeness: In order to be polite, $\mathrm{S}$ expresses or implies the meanings that associate a favourable value with what pertains to $O$ or associates an unfavourable value with what pertains to $S(S=$ self, speaker). (Leech, 2014, p.90)

His General Strategy of Politeness (GSP), which is "directed toward concord and facemaintenance" (Leech, 2014, p.221), is an extension of his original six-maxim Politeness Principle to a ten-maxim model and, relevant to my research, is complemented by the General Strategy of Impoliteness (CSI) which, contrary to GSP, is "directed towards discord and face-attack" (Leech, 2014, p.221). Another important change which Leech made was replacing his earlier (admittedly misleading) notions of "absolute" politeness and "relative" politeness with "pragmalinguistic" politeness

\footnotetext{
${ }^{3}$ When it comes to participants' facework in Charlie Hebdo discourse, I differentiate between participants' intentions and the outcomes of their acts, between the perspective of the producer, whose acts (cartoons) carry a significant load of facethreat (as an illocutionary force), and that of the receiver's, who may actually interpret that potential as a face-attack (a perlocutionary effect); note that for O'Driscoll (2011) face-attack can be both an attempt and an achievement. The two perspectives mirror the differing focus on the speaker's intentions and hearer's interpretations as they emerged in the two waves of politeness research discussed in 1.1 and 1.2 .
}

and "sociopragmatic" politeness, whereby he makes a distinction between politeness attributed to an utterance out of context and in context respectively. While both attributions are scalar, pragmalinguistic politeness is assessed on a unidirectional scale (with a possibility of gradual intensification from non-politeness towards more politeness), and the sociopragmatic politeness scale is bi-directional in that it enables context-dependent evaluations of an utterance as polite or impolite (or even underpolite, overpolite, rude etc.). Although the degrees of politeness assessed on the two scales tend to correlate, i.e. a pragmalinguistically $\mathrm{im} /$ polite utterance is typically also evaluated as a sociopragmatically im/polite one, in particular contexts the correlation need not always pertain - people may evaluate a certain social action as (sociopragmatically) "impolite" despite the (pragmalinguistically) "polite" form of an utterance. This distinction between the two sources of politeness evaluations is a crucial claim that Leech raises against the relativist positions of postpragmatic politeness theorists by his maintaining that there is a "default" politeness value of an utterance which participants rely on when there is no reason to think otherwise.

\section{Objectives, methodology and data}

In the paper I attempt to examine a particular instance of metadiscourse of impoliteness which took place in the selected papers dealing with the Charlie Hebdo attack where the aspects of the "moral orders" underlying the social actors' (satirists', attackers', the general public's) worldviews are raised and whose (ideological) foundations are thus challenged and/or contested. My main objectives are:

- to examine the metapragmatic awareness of the participants present in the metadiscourse commentaries and to search for their own (emic) understandings of $\mathrm{im} /$ politeness by closely scrutinizing their $\mathrm{im} /$ politeness evaluations;

- to demonstrate that the impoliteness discourses in the examined media are the sites of struggles over the values, and ideological foundations, of the respective moral orders upon which the given sociocultural groups are built; it is through the participants' recourse and/or appeals to various layers of moral orders that their value systems are negotiated and reified 
(including their understandings of the value of freedom of expression);

- to apply Leech's (2014) model of impoliteness to account for the participants' evaluations while viewing them from the perspective of "politeness as social practice", which upholds the existence of a multiplicity of perspectives and understandings of politeness.

\subsection{Methodology}

In my analysis of the Charlie Hebdo (meta)discourse (CHHD), Kádár and Haugh's (2013) "politeness as social practice" (PSP) approach is adopted and complemented by Leech's (2014) "neo-pragmatic" model to account for (im)politeness evaluations made by the social actors. From PSP the notion of the multiplicity of understandings of (im)politeness is employed as arising from the four perspectives which people may adopt to view a particular social action, such as $\mathrm{CHH}$ satirical practices; the four perspectives, or "loci" of politeness evaluations, are summarized in Figure 1 where the centre of the converging perspectives is occupied by $\mathrm{CHH}$ practices (the centre can be replaced by the other two evaluative moments analysed in the paper, i.e. the Je suis Charlie stance and the attack on $\mathrm{CHH}$ staff). These four understandings can be seen as jointly contributing to a more nuanced and holistic understanding of politeness arising in CHHD. What is more, they are not equally salient in every account of the evaluative moment; none of them is seen as privileged and they are not mutually exclusive as more than one may be present in one person at the same time.

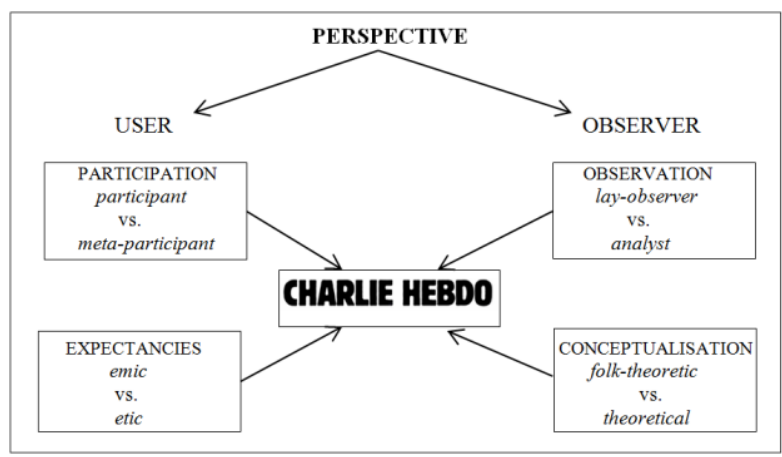

Figure 1: PSP perspectives in $\mathrm{CHH}$ discourse (based on Kádár and Haugh, 2013)

Next, drawing on and extending Goffman's notion of "participation framework" (1979, 1981), PSP offers a typology of "participation status", i.e. positions which people adopt in relation to talk or conduct which are associated with respective, albeit mutually related, evaluations of politeness and which are subsumed under the broader categories of "producers" and "recipients" (which are extensions of Goffman's original folk categories of "speaker" and "hearer"). Each category is seen to entail certain participation footings (Goffman, 1979, 1981), viz. roles and responsibilities in interaction which form mutually aligned sets of "production footings" and "reception footings" and which are encompassed within a participation framework of those involved in an interaction.

Given this, it is suggested that in the analysed CHHD the following rather complex array of participation statuses and participation footings may be identified (cf. Kádár and Haugh, 2013; Culpeper and Haugh, 2014) (see Figure 2). If we adopt here the perspective ${ }^{4}$ that the $\mathrm{CHH}$ shooting which triggered the Je (ne) suis (pas) Charlie movements, was initiated by the $\mathrm{CHH}$ satirical practices whose purpose was to further intimidate "extremists", we may consider, on the production side of participation, the $\mathrm{CHH}$ staff as occupying the following footings: an utterer (animator) by producing the cartoons, an author by designing them, and a principal by representing their beliefs in the cartoons and assuming responsibility for their content. On the reception side of participation, the complementary footings

${ }^{4}$ The viewpoint is attested to not only in some of the journalists' opinions in the articles analysed but also in the introductory post in the discussion forum underneath the article (my emphasis): Charlie and co should have known that terrorism is a threat to Europe and civilisation altogether and to fight terrorism you shouldn't add fuel to the fire and generally insult the faith of millions of Europe who are peaceful and demand respect for their faith like any true adherent of their faith would. This means if the paper wanted to challenge Islamic ideas that are hard to understand, then a rational approach and consistent arguments would be far more effective in penetrating the thick skulls of the people that join such extreme movements and not polarise them further with hate speech and racist mockery. http://www.theweek.co.uk/worldnews/charlie-hebdo/62060/seven-reasonswhy-people-are-saying-je-ne-suis-pas-charlie 
occupied by the "Islamic terrorists" are a recipient who receives the message of the cartoons, an interpreter who develops their understanding of the authors' message, and an accounter who holds the principal responsible for the content of the cartoons. As to the production footing of figure and the reception footing of target, they are in both cases represented by "Muhammad", who is a character portrayed in the cartoons. Even more complex is the participation status, or the participants' reception roles participants that arise in this situation, and it may well be the case that they are not always clear and straightforward. What is more, in the case of mediated forms of communication, they may become blurred. In the perspective outlined above, the "extremists" can be seen as ratified recipients who are directly addressed by the cartoons, hence they are the addressees to whom the obnoxious and offensive message is (ostensibly) directed. However, when we think of $\mathrm{CHH}$ as a magazine, it is the readers (we may see them as assuming the role of ratified side-participants) who are also expected to receive the message of the cartoons and hold their producers morally accountable for their meaning, and who may thus become a source of (im)politeness evaluations (it is noteworthy that the number of readers grew enormously worldwide as the circulation of the magazine rose immediately following the attack and during the weeks that followed).

The rest of the public (in France, Europe, the Western world, etc.) could be categorized as unratified recipients with a differing degree of involvement and interest in the communication and who, as bystanders, may be expected to be able to follow $\mathrm{CHH}$ satirical journalism or, as overhearers, to follow some parts of it (the remaining categories of listeners-in and eavesdroppers are too uncertain as to their membership to be further detailed in this discussion). The reception role of an audience can be used as a uniform category for ratified and nonratified recipients with a differing entitlement and/or responsibility to respond or react to the message and who may be seen as (meta)participants who "vicariously" take part in interaction in which "impoliteness" can become a "form of entertainment" (cf. Kádár and Haugh, 2013, p.90, 93). Due to the gradual blurring of the distinction between "traditional" and "digital" forms of communication, the line between participation and meta-participation also becomes increasingly blurred.

A simplified version of Kádár and Haugh's (2013) types of participation status and production and reception footings is presented in Figure 2. It is to be noted that each of these footings and statuses are sources of particular understandings and evaluations of (im)politeness ${ }^{5}$.

${ }^{5}$ Leech (2014) comes close to PSP at least in two ways: first, he makes room for other than the hearer status by using the category of Other, in which he includes the hearer and other third-persons who are recipients of politeness (hence "third-person politeness"); and, second, that politeness evaluations are made by both the "speaker" and the "hearer", with both of them following their own paths of problem solving.

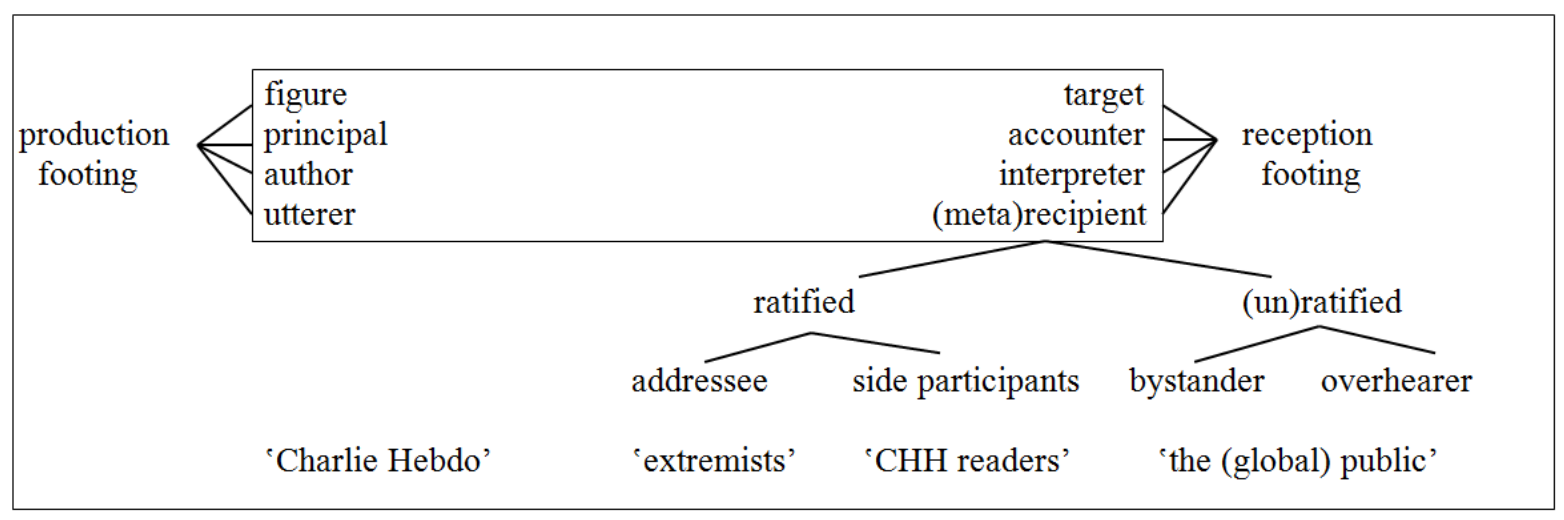

Figure 2: Types of participation status and participation footings in $\mathrm{CHH}$ satirical journalism (based on Kádár and Haugh, 2013, p.128) 
Besides the (meta)participants' understandings of politeness there are three other loci of understandings of (im)politeness evaluations represented by other social actors involved, or even by the same actors assuming other perspectives from which to evaluate the given social actions (cf. Figure 1). First, the analysed newspaper article exemplifies a secondorder discourse, viz. "Charlie Hebdo metadiscourse" in which the journalist discourses on seven other discourses, i.e. news articles on the attack. From their observer perspective, the journalists can be seen as adopting a "lay-observer" perspective of (im)politeness and as conceptualizing the incident in "folk-theoretic" terms.

Next, as the author of a paper on the (im)politeness evaluations in CHHD who is attempting to apply the most recent theoretical and methodological findings of politeness theoreticians, I can see myself as assuming the "analyst" and the "theoretical" perspective of the social action(s) under scrutiny. Using the terminological apparatus of the approach to politeness seen as social practice, my goal is to search for (meta)participants' (emic and etic) understandings of $(\mathrm{im})$ politeness manifested in their use of (im)politeness evaluators. Finally, as private persons (whether systematically or haphazardly) following the incident and its aftermath, both the journalists and myself develop our "layobserver" interpretations of what happened which are based on our own "folk-theoretic" conceptualizations. As members of our respective lingua-cultures (nation states or larger entities such as the European Union, globalized World, etc.), we are all (meta)participants of the events who import our own emic and/or etic evaluations informed by the respective moral orders to which we orient into the (meta)discourses we (help) construct on the daily basis. Thus, in the globalized world interconnected via mass-/social media networks it is difficult to disassociate "observer" from "user" perspectives of the same phenomena, since the global audiences are dispersed and less clearly demarcated. In fact, we oscillate between these two perspectives which may be co-present in the same persons, and at any given moment of evaluation neither can be completely ruled out, although one may be more salient than the other. As individuals we are involved, or at least implicated, in evaluations through our affiliations with respective moral orders whose multiplicity engenders a multiplicity of evaluations.

\subsection{Data}

The $\mathrm{CHH}$ discourse chosen as the data serves the purpose of accessing the participants' awareness of the relational aspect of language use, i.e. of how social goals are met (the "how" aspect of the quote above) along with illocutionary goals (the "what" aspect of the quote) by looking at the metapragmatic comments which they use to make (implicit or explicit) appeals to the underlying $\mathrm{MO}(\mathrm{s})$ which are occasioned by the social actions. These meta-commentaries of social actions are, by representing both conceptualizations AND understandings and/or evaluations of what had happened, are a form of social practice themselves, and my goal as an analyst is to "tap into the reflexive awareness of such evaluative moments on the part of participants (and observers) themselves" (Kádár and Haugh, 2013 , p. 186). The major methodological problem is that this awareness need not always be clearly articulated, often simply because participants are not able to do it, and if they are, then the articulateness may be a matter of degree on a scale between saliency and subtlety ${ }^{6}$. Using the PSP

6 The notion of salience is used here to address the fact that in communication, the making of choices always takes place with some degree of participants' reflexive awareness: while some choices are made on a subliminal level, others are more or less consciously controlled. Salience is "a function of the operation of the reflexive (or, as we call it, 'meta-pragmatic') awareness involved in language use" (Verschueren, $1999, p .67)$. The degree of salience is impossible to measure in any precise terms, yet its relevance is in some instances of language use made more noticeable than in others. Whenever politeness-related evaluations are made, the social acts under evaluation are "socially salient", i.e. they are more marked because they are seen as departing in some ways from established social norms, or moral orders, within respective social groupings. The metalinguistic evaluators, the "emic" terms and the expressions from the semantic field of politeness which form the "metapragmatics of politeness", are the manifestations of this salience, since as indicators of participants' reflexive awareness they index their reflexive 
approach, I focus on the four types of metapragmatic awareness which give a "window into the reflexive layers of the moral order" (Kádár and Haugh, 2013, p.187): metalinguistic awareness, i.e. expressions used to talk about politeness, meta-communicative awareness, i.e. explicit commentaries by participants which represent their interpretations/evaluations of social actions, metadiscursive awareness, i.e. social discourses on politeness which offer "a persistent frame of interpretation and evaluation that has become objectified in ongoing metapragmatic talk about politeness (Kádár and Haugh, 2013, p.187)", and metacognitive awareness, i.e. presentations of cognitively grounded states (attitudes, expectations, etc.).

As to the structure of $\mathrm{MO}$ itself, it is a layered construct consisting of expectations which are grounded in three sets of norms representing three layers of MO: localized norms (formed by individuals), group-based norms (shared among sociocultural groups) and societal/cultural norms. All three layers draw on (im)politeness evaluators (metalanguage) which are conceptualized by members and which we need to investigate in order to access their own (emic, insider) perspective on a social action. This should be, however, complemented by the nonmembers' (etic, outsider) perspective(s) as these are also formulated in the media discourses. It is through the latter perspective that we can systematically investigate the ways the "same" action is conceptualized across cultures, which is essential in interactions which involve members of different cultures with possibly differing perspectives/evaluations of the "same" social action.

At the core of metapragmatic awareness are politeness-related evaluators, i.e. metalinguistic expressions used by participants to conceptualize their politeness evaluations and which belong to the semantic field of "politeness". They are

understandings of "(im)politeness". In the analysis these indicators are discussed with the point being accentuated that they are the clues to access the participants' own conceptualizations of what is "(im)polite" since "there is no way of understanding forms of social behaviour without gaining insight into the way in which the social actors themselves habitually conceptualize what it is they are doing" (Verschueren, 1999, p.196). valenced in the sense that they are (emotively) charged on the scale of (in)appropriateness; for example, "polite" is positively valenced. It must be added that not only are evaluators not valenced consistently (besides their occupying similar/overlapping conceptual spaces) but that in locally situated interactions their valence can be judged differently, or even contrarily to their inherent valence (cf. Leech's sociopragmatic politeness). An important thing is that the valences of these (sets of) mutually related evaluators are not made idiosyncratically but are negotiated (i.e. struggled over) over time and space by members of social groups who use them as a normative frame of reference, i.e. the assumption that other members would evaluate the social actions similarly (cf. Leech's pragmalinguistic politeness). It should be mentioned that metapragmatic awareness is also manifested through other linguistic expressions which, rather than being inherently polite, "lend themselves to individual interpretation as 'polite'" (Watts, 2003 , p.168). These "formulaic and semiformulaic expressions of linguistic politeness" (Watts, 2003) are a frequent object of attention in analyses of political discourse, such as hedges in political speeches by Miššíková (2007), along with communicative strategies stretching over entire sequences of political discourses, (cf. Dontcheva-Navratilova, 2007; Rázusová, 2008).

The CHHD data for the present analysis is represented by the news article Seven reasons why people are saying 'Je ne suis pas Charlie' which is available on the internet version of the periodical The Week ${ }^{7}$ and which has for several months been freely accessible as the first English article listed when a crude Google search for the results of the Je ne suis pas Charlie slogan is carried out. In terms of Google hits (in April 2015), the Je ne suis pas Charlie discourse comes second after the Je suis Charlie discourse and before other discourses appended to the related slogans in English, such as I am Charlie; I am not Charlie. As an example of a metadiscourse on $\mathrm{CHH}$ attack, the article references seven other articles reporting on the attack (see Figure 3).

${ }^{7}$ http://www.theweek.co.uk/worldnews/charlie-hebdo/62060/seven-reasonswhy-people-are-saying-je-ne-suis-pas-charlie 


\begin{tabular}{|c|c|c|c|c|}
\hline & journalist & published & article title & newspaper \\
\hline & N/A & $14 / 1 / 2015$ & $\begin{array}{l}\text { Seven reasons why people are } \\
\text { saying 'Je ne suis pas Charlie' }\end{array}$ & The Week \\
\hline Al & Roxane Gay & $12 / 1 / 2015$ & $\begin{array}{l}\text { If je ne suis pas Charlie, am I a } \\
\text { bad person? Nuance gets lost in } \\
\text { groupthink }\end{array}$ & The Guardian \\
\hline A2 & $\begin{array}{l}\text { Michael } \\
\text { Tomasky }\end{array}$ & $12 / 1 / 2015$ & $\begin{array}{l}\text { The Right and Wrong Reasons } \\
\text { for Outrage }\end{array}$ & Daily Beast \\
\hline A3 & David Brooks & $8 / 1 / 2015$ & I Am Not Charlie Hebdo & New York Times \\
\hline A4 & $\begin{array}{l}\text { Brendan } \\
\text { Bordelon } \\
\text { (Salah-Aldeen } \\
\text { Khadr } \\
\text { Mohamed Vall } \\
\text { Salem) }\end{array}$ & $9 / 1 / 2015$ & $\begin{array}{l}\text { 'I AM NOT CHARLIE': Leaked } \\
\text { Newsroom E-mails Reveal Al } \\
\text { Jazeera Fury over Global } \\
\text { Support for Charlie Hebdo }\end{array}$ & National Review \\
\hline A5 & $\begin{array}{l}\text { Robert } \\
\text { Shrimsley }\end{array}$ & $8 / 1 / 2015$ & $\begin{array}{l}\text { Be glad someone had the } \\
\text { courage to be Charlie }\end{array}$ & Financial Times \\
\hline A6 & Simon Kelner & $13 / 1 / 2015$ & $\begin{array}{l}\text { I am no more Charlie than } \\
\text { George Clooney or Helen Mirren } \\
\text { is }\end{array}$ & The Independent \\
\hline A7 & Sam Leith & $12 / 1 / 2015$ & $\begin{array}{l}\text { Sam Leith: We are not Charlie, } \\
\text { and none of us has totally free } \\
\text { speech }\end{array}$ & $\begin{array}{l}\text { London } \\
\text { Standard }\end{array}$ \\
\hline
\end{tabular}

Figure 3: A survey of the analysed $\mathrm{CHH}$ metadiscourse

As to the social semiotics of the cartoons, two particularly useful approaches are available: the grammar of visual design (Kress and Van Leeuwen, 1996) and the Hallidayan framework of language metafunctions (Halliday, 1978). Being multimodal communicative acts, satirical cartoons can be seen as combining visual and verbal codes which draw on modespecific resources and "grammars" and whose particular constellations are employed to complement and/or reinforce one another in order to convey a composite (satirical) meaning. Visually, a CHH cartoon represents a "picture", i.e. an "image or text or combination of image and text that forms a coherent single-framed sign" (Scollon and Scollon, 2003, p.214) whose construction elements, or participants, are arranged to form conceptual or narrative structures, by representing participants and/or by presenting unfolding actions. Thus, a $\mathrm{CHH}$ cartoon ${ }^{8}$ may portray the Prophet Muhammad alone uttering a message and, through eye contact, addressing the viewers/readers, in which case the image realizes a "demand" of something from the

${ }^{8} \mathrm{http} / / /$ www.huffingtonpost.com/2015/01/0 7/charlie-hebdo-cartoons-paris-frenchnewspaper-shooting_n_6429552.html viewer; or it may present an "offer", in which other interacting characters are "objects of contemplation, impersonally, as though they were specimens in a display case" (Kress and Leeuwen, 1996, p.124).

If we adopt the familiar Hallidayan framework (Halliday, 1978) of communicative metafunctions to trace the simultaneous presence of the three levels of meaning in the cartoons, i.e. ideational, interpersonal and textual, we can observe that the overall visual design of the cartoon can be seen as a realization of the textual metafunction by combining visual resources into intertwined wholes which are recognisable as instances of the genre of political satire. The capacity of the textual metafunction is also to integrate the other two functions which find their way into the texts by means of their function-specific means: the ideational metafunction constructs particular representation of the world through the choice of participants and the propositional content of their utterances (the latter provides the discourse with the its lexical-semantic layer, or "field"), and the interpersonal metafunction constructs the relationships between the cartoon authors and their recipients, as well as between both of them and that which the cartoons represent. The immediate means of addressee involvement is the performance of speech acts, whether linguistic or non- 
linguistic, with their respective illocutionary forces and the expected perlocutionary effects conventionally associated with the genre of political satire. In summary, a $\mathrm{CHH}$ cartoon can be considered a "single, multilayered, multimodal communicative act, whose illocutionary force comes about through the fusion of all the component semiotic modes" (Van Leeuwen, 2005, p.121).

\section{Analysis and discussion ${ }^{9}$}

The analysed CHHD offers an aperture to how, through societal-level debates about (in)appropriateness of social actions, social metadiscourses on (im)politeness emerge. People's evaluations of social actions index their multiple understandings of politeness vis-à-vis the normative frames of reference established within the respective social groups. I suggest there are three such social actions/evaluative moments which are objects of participants' evaluation in the analysed metadiscourse: (1) the Je suis Charlie stance, (2) the $\mathrm{CHH}$ journalistic practices and (3) the attack on the $\mathrm{CHH}$ staff. Using the PSP framework, from my observer's viewpoint of an analyst/theoretician, I attempt to analyse the metadiscourse using Leech's model of impoliteness (CSI). The analysed metadiscourse is one such example of situated evaluations in which judgements of (in)appropriateness are made in particular contexts; this means that a degree of variability reflecting the contested nature of politeness is expected.

In the PSP perspective, the evaluative moment is a locus of several interrelated understandings of politeness on the part of the journalist who can be seen as the producer of the metadiscourse evaluating the evaluations of other journalists and displaying emic, lay-observer and folktheoretic understandings of politeness. His production footing involves the roles and responsibilities of the utterer, of the author of his own evaluations and of the principal who can be held responsible for these evaluations. The recipients (readers) are not directly involved in the metadiscourse although their evaluations can be anticipated

\footnotetext{
${ }^{9}$ To distinguish between scientific/technical ( $2^{\text {nd }}$ order, etic) terms and actually used layperson's ( $1^{\text {st }}$ order, emic) evaluations I use double quotation marks (") and italics, respectively.
}

as perlocutionary effects. Although they are best viewed as mutually overlapping, in the following analysis the three social actions involved in the metadiscourse and the respective frames (moral orders) of their interpretation and evaluation invoked by participants are examined separately.

\subsection{The Je suis Charlie stance vis-à-vis understandings of (im)politeness}

The first evaluative moment through which politeness arises challenges the Je suis Charlie stance. At the beginning of the article, the author underscores the evaluative nature of the social action of the $\mathrm{CHH}$ attack by pinpointing that it elicited two contradictory evaluations on the part of the (meta)recipients: while "millions of people" declared Je suis Charlie, "some people" claimed Je ne suis pas Charlie. The body of the article consists of a survey of these latter evaluations which come from seven different journalistic sources and which are presented as "seven reasons" for the disagreement with, and disengagement from, the Je suis Charlie stance. The "reasons" are extracted from the individual articles and presented by the journalist in the form of seven subheadlines. It is noticeable that all the subheadlines which articulate the journalist's evaluations of the inappropriateness of the Je suis Charlie stance invoke particular layers of the MO:

(1) Groupthink makes it difficult to express nuance; (2) Intolerance provoked this violent reaction; (3) The hypocrisy of "hate speech"; (4) "Baiting extremists isn't bravely defiant"; (5) I am not brave enough; (6) Tricky issue cannot be reduced to a slogan; (7) Free speech is not a simple good.

Looked at from Leech's (2014) pragmalinguistic, i.e. decontextualized politeness perspective, the proponents of the Je ne suis pas Charlie stance can be seen as acting "impolitely" by blatantly violating the Agreement Maxim of his GSI, viz. acting in accordance with the impoliteness maxim "give(s) an unfavourable/low value to O[ther]'s opinion" (Leech, 2014, p.221). However, viewing it from the (contextualized) PSP perspective we are not in a position to make such a straightforward claim since no immediate feedback from the receivers is available. All we can do is to search for evaluations in the articles reported on and look for the descriptive metalanguage which participants use to conceptualize their social worlds. More specifically, we can focus on those 
expressions through which participants index their evaluation of the social action. In the case of adopting the counter-Je suis Charlie stance, we look at which "expected background features of everyday scenes that members of a sociocultural group or relational network 'take for granted"' (Kádár and Haugh 2013, p.269) are used as normative frames of reference to which participants are seen to orient themselves when making their evaluations. These "features" are certain important aspects of the MO which they see as being compromised by the proponents of the Je suis Charlie stance and which they (implicitly) evaluate as "inappropriate". This evaluation is grounded in all three layers of the MO.

First, the Je suis Charlie stance is seen as taking some important societal/cultural norms ( $3^{\text {rd }}$ layer of $\mathrm{MO} /$; or $\left.\mathrm{MO}^{3}\right)$ to extremes or as misusing them:

- thinking alike in order to express solidarity (i.e. "groupthink") diminishes room for other opinions (sub-headline/article 1),

- unrestrained exercise of freedom of speech is a form of intolerance and can become a source of provocation (sub-headline/article 2),

- as far as public criticism is concerned, double standards exist in (US) society: while offending "Islamic terrorists" is tolerated, some home critics are "snubbed" (subheadline/article 3),

- while the slogan is an exercise of freedom, it is an "empty expression" which simplifies a complex matter (sub-headline/article 6),

- free speech is not unconstrained, it is "de jure unfree" (sub-headline/article 7).

- Next, the group-based norms $\left(2^{\text {nd }}\right.$ layer of $\mathrm{MO}$; or $\mathrm{MO}^{2}$ ) are disputed with the claim that $\mathrm{CHH}$ journalists, rather than defending the freedom of expression, insisted on their right to be obnoxious and offensive, which offended "millions of moderate people" (sub-headline/article 4).

Finally, the localized/individualized norms ( $1^{\text {st }}$ layer of $\mathrm{MO}$; or $\left.\mathrm{MO}^{\prime}\right)$ are invoked when personal hypocrisy and a lack of courage are seen as the motivation for one's identification with $\mathrm{CHH}$ (sub-headline/article $5)$.

Whether or not the recipients (readers) actually evaluate this counter positioning as "inappropriate", or as "impolite" (Leech) is difficult to ascertain without using proper methods. One of them is examining the discussion forum which accompanies the article and which is a rich source of data about sociopragmatic (in-context) politeness evaluations, since it can be assumed that the commenters joined the forum in order to position themselves with regard to the Je suis Charlie stance. Obviously, through their use of linguistic forms and expressions, including (im)politeness evaluators, these commenters display their evaluations of the other two social actions as well.

\subsection{Charlie Hebdo journalism vis-à-vis understandings of (im)politeness}

The multiple perspectives of the social action assumed by the journalists whose individual articles are reported on in the metadiscourse certainly yield multiple understandings of politeness. As (meta)recipients, these people may be either ratified as side-participants by being $\mathrm{CHH}$ readers, or unratified as, for example, members of the (global) public at large (cf. Figure 2).

When making their evaluations of $\mathrm{CHH}$ journalistic practices, the journalists place $\mathrm{CHH}$ and their addressees into the focus of their evaluations and hold them accountable with regard to the the layers of the MO which they invoke. Through this, the discourses that they engender become ideologically charged since they address the principal values upon which the societies are based. More often than not, these evaluations are to be inferred since they are implied rather than explicitly stated.

In her evaluation of the $\mathrm{CHH}$ journalism, Roxane Gay (A1) invokes all three layers of the $\mathrm{MO}$ : while she personally $\left(\mathrm{MO}^{\prime}\right)$ evaluates (some) $\mathrm{CHH}$ work $\left(\mathrm{MO}^{2}\right)$ as distasteful, i.e. negatively marked as "inappropriate", she believes in the authors' right to be so, even at the expense of expressing an offense, since she recognizes freedom of expression as a privileged societal convention $\left(\mathrm{MO}^{3}\right)$. By implication, on the societal level, $\mathrm{CHH}$ satirical journalism as a way of exercising freedom of speech may be deemed as an "appropriate" type of behaviour whose negative, and potentially offensive, portrayal of the target of satire is an expected, and unmarked, form of social practice $^{10}$.

${ }^{10}$ Watts $(2003$, p.260) notes that in certain types of interaction, such as close-knit family encounters, competitive political debates, 
Although the three layers of $\mathrm{MO}$ are generally understood as reflexively ordered, i.e. $\mathrm{MO}^{3}$ expectancies take precedence over both $\mathrm{MO}^{2}$ and $\mathrm{MO}^{1}$ expectancies, Roxane Gay reverses them by formulating an ad hoc norm of a "freedom ... to express offence" which is to be applied when certain (individual or group-based) norms are breached. However, while she may be considered to be empathizing with the addressees, she evaluates their behaviour as "inappropriate" by holding them accountable for violating a supra-local $\left(\mathrm{MO}^{3}\right)$ moral principle which she formulates as "murder is not an acceptable consequence of anything". In a similar vein, Bill Donohue (A2) evaluates $\mathrm{CHH}$ practices as negatively marked, hence "inappropriate/impolite", by using the metalinguistic terms and expressions with negative connotations to conceptualize the precursor of the particular incident (the vulgar manner in which Muhammad has been portrayed) as well as their journalism over a longer period of time $([\mathrm{CHH}$ had a] long and disgusting record of going way beyond the mere lampooning of public figures). Identified as president of the Catholic League, i.e. a member of a community marked by conservative opinions (which are derived from particular $\mathrm{MO}^{2}$ norms), he dismisses $\mathrm{CHH}^{2} \mathrm{M} \mathrm{MO}^{2}$ norms which caused Muslims to be intentionally insulted over the course of many years. By raising the issue of the recognition of intentionality" on the part of the Muslims, Bill Donohue underscores the severity of the face-attack which is built into $\mathrm{CHH}$ journalism as its (planned) perlocutionary effect. From the perspective of his understanding of politeness, Bill Donohue evaluates the behaviour of the two parties in the conflict as "inappropriate", as

communities marked by rigid hierarchies etc. face-threatening/damaging acts may be sanctioned or neutralized; as so-called "sanctioned aggressive facework", they may be considered expected, and "appropriate", forms of social practice. Political satire can be included among such types of interaction in which "face-attacking ... plays a central role, and thus might be said to be "normal'" (Culpeper, 2008, p.29).

"Some politeness researchers suggest that the perception of the presence of intention is decisive in evaluating certain behaviour as face-attacking (cf. Culpeper, 2008). manifestations of intolerance, and a violation of the $\mathrm{MO}^{3}$ norm. On the other hand, by his positioning as I am in total agreement with them with regard to the vulgar portrayals, Bill Donohue's position may be seen as a demonstration of "politeness" towards "Muslims", by explicitly adhering to the Agreement maxim of Leech's GSP, viz. "Give a high value to O's opinions"; Leech, 2014, p.91).

Like Roxane Gay, David Brooks (A3), as a US cultural insider, finds the contradiction between people's orientation to the localized/individualized (MO') norms and CHH's group-based $\left(\mathrm{MO}^{2}\right)$ norms as the reason why they evaluate the latter negatively as "impolite" or even "rude"'2: most of us don't actually engage in the sort of deliberately offensive humour that that newspaper specialises in. In addition to that, he makes his non-European outsider/etic identity salient and invokes the multiplicity of the society-level $\left(\mathrm{MO}^{3}\right)$ norms within the (Western) world which, among other values, professes freedom of speech: he finds a flaw within the US society's MO, which is seen as selective with regard to the implementation of this freedom: A lot of people are quick to "lionise" those who offend Islamist terrorists but are a lot less tolerant toward those who offend their own views at home. The implied evaluator of this practice as hypocritical is yet another example of the negative evaluation of the existing societal ethos.

Another outsider/etic (non-European/nonWestern) locus of impoliteness evaluation is represented in A4 by Al Jazeera English editor Salah-Aldeen Khadr and reporter Mohamed Vall Salem. The target of their negative (sarcastic, and thus potentially "impolite") evaluation is the abuse of free speech by $\mathrm{CHH}$, who interpreted the right of free speech as the right to be obnoxious and offensive. They also draw attention to the side-participants' evaluative perspective, i.e. that of the millions of moderate people who they claim have been offended by $\mathrm{CHH}$ journalism. Finally, while admitting the legitimacy of the content of the cartoons (the what), they argue against its interpersonally damaging effects (the how),

12 Sometimes a distinction, although not unequivocal, is made between impoliteness and rudeness, based on the presence of intention in the former (Culpeper, 2008) or the latter (cf. "marked rudeness", or "rudeness proper"; Terkourafi, 2008). 
which is the object of their negative "impolite" evaluation: It's not about what the drawing said, it was about how they said it. One other thing that the article does is to point out the "scale-shift" whereby $\mathrm{CHH}^{2} \mathrm{~s}$ $\mathrm{MO}^{2}$ practices are transferred to the societal $\left(\mathrm{MO}^{3}\right)$ level, and which they deem as an abuse of free speech.

Robert Shrimsley's article (A5) stands out from among other articles in that it accumulates positive metalanguage of $\mathrm{CHH}$ journalism: [they were] maddeningly, preposterously and - in the light of their barbarous end - recklessly brave, ready to defy real death threats and firebomb attacks. This face-enhancing strategy, which is potentially interpretable as "polite", can be seen as upholding Leech's GSP, although the motivation is somewhat less altruistic than expected; the author admits the fault in his individual $\mathrm{MO}^{\prime}$ when he emotionally and morally approves of $\mathrm{CHH}$, but what prevents him from declaring his support overtly is his lack of courage to take this kind of risk. What is more, he "scale-shifts" this selfassigned negative moral trait to a larger collectivity of those who sit safely in an office in western Europe [...] who would never contemplate taking the kind of risks. The extension of an individual (MO') moral trait and its attribution to the other layers of the moral order $\left(\mathrm{MO}^{2 / 3}\right)$ is in itself an evaluative moment which may result in a potentially negative "impolite" evaluation from readers of the article.

Simon Kelner's (A6) evaluation of $\mathrm{CHH}$ journalism as "inappropriate" can possibly be arrived at by drawing an inference from his saying that it is a tricky and complicatedsituation to which there are no easy answers. Also, he takes issue with the moral integrity of a society (and invokes the $\mathrm{MO}^{3}$ norms) which maintains double standards regarding the application of freedom of speech: while implying that it is tolerant of CHH's anti-Muslim practices, he casts serious doubt on whether it would equally tolerate a display of extreme rightwing beliefs. Similar to Roxane Gay (A1), Simon Kelner endorses the exercise of the freedom of speech as the ultimate liberty within the society's moral order.

Finally, Sam Leith's (A7) negative evaluation of $\mathrm{CHH}$ practices as "inappropriate" is implied by his maintaining that free speech is both de jure and de facto unfree on the societal, group and individual levels. $\mathrm{He}$ further implies that the $\mathrm{CHH}$ satire as an exercise of freedom, the value of which tends to be regarded as the ultimate $\mathrm{MO}^{3}$ norm, is only illusionary: The law may not stop me calling you a $n^{* * * * *}$, but that doesn't mean I take an important stand for liberty by doing so. Also, he pinpoints the meta-participatory status of "us" - the audience of $\mathrm{CHH}$ attack, by underlining the vicarious nature of our taking part in it, by enjoying a nice, self-affirming, essentially infantile holiday from difficulty; the implied criticism is in itself an evaluative moment which may be interpreted as "inappropriate", or "impolite".

\subsection{The attack on the CHH staff vis-à-vis understandings of (im)politeness}

In contrast with the other two social actions, the grave attack on $\mathrm{CHH}$ staff may at first glance resist any analysis using politeness theory; aggressive physical behaviour resulting in death may be seen as indescribable using the technical vocabulary of "politeness" theorization. Thus the question arises whether or not we are stretching the concept and theorization of "politeness" to its limits since "it is problematic to call somebody 'impolite' who has harmed a person physically" (Limberg 2008 , p. 167). Yet as a maximum degree of face aggravation involving physical rather than verbal violence, death as a result of physical harm may be seen as an extreme case of the application of GSI: "Give an unfavourable value to O's wants"; Leech, 2014, p.221). As (im)politeness always involves scales, some extreme types of conflictual verbal behaviour, which Leech (2014, p.223) classifies as "naked affront" or as "rudeness" rather than "impoliteness", border on physical violence and may lead to an assault.

Regarding the attack on $\mathrm{CHH}$ staff, a noticeable thing is that only three of the seven articles are quoted to evaluate the murders explicitly negatively as "impolite", with the metalanguage used varying between mild and heavy criticism to: not acceptable (A1), violent (A2), heinous (A4). In addition to the use of evaluative language, these journalists are seen as trying to rationalize the action by calling to attention the fact that the victims could have anticipated the attack on them, as in Baiting extremists isn't bravely defiant (A4), and neither should we tolerate the kind of intolerance that provoked this violent reaction (A2). A special case of evaluation is Roxane Gay's (A1), which, in addition to condemning the killings by suggesting that Murder is not an 
acceptable consequence for anything invokes the existence of a transsocietal/cultural layer of moral order, or $\mathrm{MO}^{4}$, which she construes as one in which life is seen as an absolute value. Another thing which underscores the multiplicity of understandings of politeness is when she expresses empathy (and "politeness") towards the murderers by defending their right to express offense, which she sees as falling within the scope of the same moral order which guarantees freedom of expression: Yet it is also an exercise of freedom of expression to express offense at the way satire like Charlie Hebdo's characterises something you hold dear - like your faith, your personhood, your gender, your sexuality, your race or ethnicity.

Here she draws attention to the value structure of a group-based moral $\mathrm{MO}^{2}$ in which faith, personhood, gender, sexuality, race, ethnicity are revered, and how their interference by an exercise of broader societal $\left(\mathrm{MO}^{3}\right)$ norms such as freedom of expression - a "scale shift" - may engender negative evaluations, which, in this case, is offense.

\section{Conclusion}

Je suis Charlie was a stance which was spontaneously created by an individual person $^{13}$ through which he displayed his evaluation of the fatal attack on $\mathrm{CHH}$ staff and demonstrated his solidarity with the victims; in politeness terms, by orienting to Leech's GSP rule, he acted in a "polite" way. This momentary expression of individual identification with $\mathrm{CHH}$ values and groupbased norms was subsequently taken up by other individuals and groups and became a collective and societal declaration of adherence to $\mathrm{CHH}$ practices $\left(\mathrm{MO}^{2}\right)$ which were endorsed by the society-based norms $\left(\mathrm{MO}^{3}\right)$ in which freedom to act (and speak) independently is an ultimate value. This "scale shift", whereby group-based norms became transferred to wider debates about the (in)appropriateness of behaviour at a societal level, can be seen as a reason why $\mathrm{CHH}$ staff were also considered to be victims of the exercise of this freedom of speech, rather than of their own group-specific practices. However, an alternative position began to form itself simultaneously from

13

http://en.wikipedia.org/wiki/Je_suis_Charlie among those who positioned themselves "against" this interpretation and who suggested that Je suis Charlie is too simplistic, and as a shorthand for a mutilayered identity, conceals more than it reveals. Hence, the emerging Je ne suis pas Charlie platform offered a voice to identify with for those who found it reasonable to disassociate themselves from the official/mainstream identity. The analysed metadiscourse offers seven such sources of this disassociation which are all based on the journalists' positioning themselves against particular layers of moral order. In my analysis I have tried to explain how authors as participants in the (im)politeness considerations evaluate the appropriateness of three social actions by orienting to the expectancies relative to the respective moral orders which they explicitly or implicitly invoke and through which they hold others accountable for their actions. My basic claim is that the methodology of "politeness as social practice" is capable of elucidating the processes of evaluation and the means which people use in making such evaluations by focusing on their own, i.e. emic understandings of politeness demonstrated by their metapragmatic awareness and manifested by the use of (implicit and explicit) evaluative resources. Ultimately, my aim is to demonstrate that evaluation of social actions is an omnipresent activity of social actors and represents a social practice in its own right through which the moral and ideological foundations of sociocultural groups are permanently reified.

Note: This publication is supported by the KEGA 030PU-4/2014 grant scheme.

Abbreviations:

$\mathrm{CHH}$ Charlie Hebdo CHHD Charlie

Hebdo (meta)discourse

GSP Grand Strategy of Politeness GSI

Grand Strategy of Impoliteness

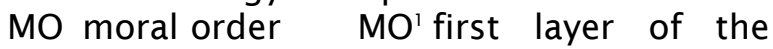
moral order

$\mathrm{MO}^{2}$ second layer of the moral order $\mathrm{MO}^{3}$

third layer of the moral order

PSP politeness as a social practice PT

Politeness Theory 


\section{References}

ARUNDALE, R.B., 2010. Constituting face in conversation: Face, facework and interactional achievement. Journal of Pragmatics, vol. 42, pp. 2078-105.

BROWN, P. and LEVINSON, S., 1978. Universals in language usage: Politeness

phenomena. In: E. N. Goody, ed. Questions and politeness. Cambridge: Cambridge University Press, pp.56-289.

BROWN, P. and LEVINSON, S., 1987. Politeness, some universals in language usage.

Cambridge: Cambridge University Press.

CULPEPER, J., 2005. Impoliteness and entertainment in the television quiz show:

The Weakest Link. Journal of Politeness Research, vol. 1, no. 1, pp. 35-72.

CULPEPER, J., 2008. Reflections on impoliteness, relational work and power. In: D.

Bousfield and M. A. Locher, eds. Impoliteness in language. Studies on its interplay with power in theory and Practice. Berlin: Mouton de Gruyter, pp. 17-44.

CULPEPER, J. and HAUGH, M., 2014. Pragmatics and the English language. Basingstoke:

Palgrave Macmillan.

DONTCHEVA-NAVRATILOVA, O., 2007. Some aspects of politeness in public speaking. Topics in Linguistics, no.1, pp. 30-35.

GOFFMAN, E., 1955. On face-work: An analysis of ritual elements in social interaction.

Psychiatry: Journal of Interpersonal Relations, vol. 18, no. 3, pp. 213-231.

GOFFMAN, E., 1979. Footing. Semiotica, vol. 25, no. 1, pp. 1-29.

GOFFMAN, E., 1981. Forms of talk. Philadelphia: University of Pennsylvania Press.

GRAINGER, K., 2011 . 'First order' and 'second order' politeness: Institutional and

intercultural contexts. In: Linguistic Politeness Research Group (eds.) Discursive

approaches to politeness. Berlin: Mouton de Gruyter, pp.167-88.

HALLIDAY, M. A. K., 1978. Language as social semiotic. London: Edward Arnold.

KÁDÁR, D. and HAUGH, M., 2013. Understanding politeness. Cambridge: Cambridge

University Press.

KRESS, G. and VAN LEEUWEN, T., 1996. Reading images: The grammar of visual design. London: Routledge.

LAKOFF, R., 1973. The logic of politeness; or minding your p's and q's. Papers from the

Ninth Regional Meeting of the Chicago Linguistic Society. Chicago: Chicago Linguistic Society. pp. 292-305.

LEECH, G., 1983. Principles of pragmatics. London: Longman.

LEECH, G., 2014. The pragmatics of politeness. Oxford: Oxford University Press.

LIMBERG, H. 2008. Threats in conflict talk: Impoliteness and manipulation. In: D. Bousfield

and M. A. Locher, eds. Impoliteness in language. Studies on its interplay with power in theory and practice. Berlin: Mouton de Gruyter, pp.155-179.

LOCHER, M., 2011. Situated impoliteness: The interface between relational work and identity construction. In: B.L. Davies, M. Haugh and A. J. Merrison, eds. Situated politeness, New York: London: Continuum International Publishing Group. pp. 187-208.

LOCHER, M. A. and WATTS, R. J., 2005. Politeness theory and relational work. Journal of

Politeness Research: Language, Behaviour, Culture, vol. 1, no. 1, pp. 9-33.

LOCHER, M. A. and WATTS, R. J., 2008. Relational work and impoliteness: Negotiating norms of linguistic behaviour. In: D. Bousfield and M. A. Locher, eds. Impoliteness in language. Studies on its interplay with power in theory and practice. Berlin: Mouton de Gruyter, pp. 77-99.

MIŠŠíKOVÁ, G., 2007. Maxim hedges in political discourse: A contrastive perspective.Topics in Linguistics, no.1, pp. 76-79.

O'DRISCOLL, J. 2011 . Some issue with the concept of face, In: F. Bargiela-Chiappini and D.

Z. Kádár, eds. Politeness across cultures. Basingstoke: Palgrave Macmillan. pp. 17-41.

RÁZUSOVÁ, M., 2008. Specific nature of question-answer exchanges of television political interview in English. Topics in Linguistics, no. 2, pp. 63-66.

SPENCER-OATEY, H. 2005. (Im)politeness, face and perceptions of rapport: Unpackaging their bases and interrelationships. Journal of Politeness Research, vol.1, pp. 95-119. TERKOURAFI, M. 2008. Toward a unified theory of politeness, impoliteness and rudeness. In: D. Bousfield and M. A. Locher, eds. Impoliteness in language. Studies on its interplay with power in theory and practice. Berlin: Mouton de Gruyter, pp. 45-74.

VERSCHUEREN, J. 1999. Understanding pragmatics. London: Arnold.

WATTS, R. J., IDE, S. and EHLICH, K., (eds.), 1992. Politeness in language: Studies in its 
history, theory and practice. Berlin: Mouton de Gruyter.

WATTS, R. J., 2003. Politeness. Cambridge: Cambridge University Press.

WENGER, E., 1998. Communities of practice. Learning, meaning, and identity. Cambridge:

Cambridge University Press.

\section{Author's address and contact details}

Milan Ferenčík, doc., PhDr., PhD.

Inštitút anglistiky a amerikanistiky

Filozofická fakulta Prešovskej univerzity

Ul.17. novembra 1

08001 Prešov

Slovak Republic

Phone: +421517570801

E-mail: milan.ferencik@unipo.sk 